\title{
Flucloxacillin-Induced Hepatotoxicity - Association with HLA-B`5701
}

\author{
Mónica Teixeira ${ }^{1}$ \\ (iD) Sara Macedo ${ }^{1}$ \\ (iD) Tânia Batista ${ }^{1}$ \\ (iD) Sofia Martins ${ }^{1}$ \\ (iD) Andreia Correia ${ }^{2}$ \\ (iD Luís Costa Matos 3,4
}

1. Internal Medicine Physician with Specific Training in Internal Medicine, Tondela-Viseu Hospital Center, Viseu, Portugal. 2. Hospital Assistant Physician in Internal Medicine, Tondela-Viseu Hospital Center, Viseu, Portugal. 3. Hospital Assistant Physician Graduated on Internal Medicine, Tondela-Viseu Hospital Center, Viseu, Portugal.

4. Faculty of Health Sciences of the University of Beira Interior, Covilhã, Portugal.

\section{SUMMARY}

Drug-induced liver injury (DILI) to flucloxacillin is rare and is classified as idiosyncratic, as it is dependent on individual susceptibility, unpredictable, and dose-independent.

The authors present the case of a 74 - year - old man with a history of monoclonal gammopathy under investigation and alcoholic habits of $24 \mathrm{~g} /$ day, with asthenia, anorexia, nausea, abdominal discomfort, and fever with three days of evolution. He was treated with two courses of antibiotic therapy with flucloxacillin to erysipelas previously (3 months and 2 weeks before admission). Lab tests showed serum AST levels of $349 \mathrm{U} / \mathrm{L}$, ALT $646 \mathrm{U} / \mathrm{L}$, alkaline phosphatase $302 \mathrm{U} / \mathrm{L}$, GGT $652 \mathrm{U} / \mathrm{L}$, total bilirubin $3.3 \mathrm{mg} / \mathrm{dL}$ and direct bilirubin $2.72 \mathrm{mg} / \mathrm{dL}$. Infectious, autoimmune, and metabolic causes were ruled out. Magnetic resonance cholangiopancreatography showed normal results. Liver biopsy showed mild multifocal (predominantly microvesicular) steatosis; marked changes in the centrilobular areas (sinusoidal dilatation, marked congestion, hemorrhage, and multifocal hepatocyte collapse); expansion of the portal areas with the formation of bridges; proliferated bile ducts and inflammatory infiltrate of variable density, predominantly mononuclear type. The HLA-B*5701 screening test was positive.

Hepatic biochemical tests remain abnormal with a significative increase in total bilirubin, which reached levels of $24.1 \mathrm{mg} / \mathrm{dL}$, with the development of jaundice, pruritus, and choluria. DILI was assumed, and the patient was treated with ursodeoxycholic acid. There was favorable evolution, without evidence of blood coagulation dysfunction or encephalopathy. The analytic normalization was, however, slow, with evolution to chronicity.

The authors present this case to remind the possibility of moderate/severe drug-induced liver injury to flucloxacillin, an antibiotic commonly used in clinical practice and association with the HLA-B *5701 allele reported in the literature.

KEYWORDS: Chemical and Drug-Induced Liver Injury. Floxacillin. HLA-B Antigens.

DATE OF SUBMISSION: 25-Apr-2019

DATE OF ACCEPTANCE: 30-Jun-2019

CORRESPONDING AUTHOR: Mónica Martins Teixeira

Internal Medicine Service, Tondela-Viseu Hospital Center

Avenida Rei Dom Duarte, Viseu, Portugal - 3504-509

Phone: 00351232420500

E-mail: monicamteixeira.9@gmail.com 


\section{INTRODUCTION}

Drug-associated hepatotoxicity is a challenge in current clinical practice, either by its reduced incidence or by the absence of specific biomarkers. The recognition and diagnosis are potentially complex due to the similarity of the clinical, laboratory, and histological presentation with other causes of liver disease. ${ }^{1.2}$

The diagnosis is clinical, based on exclusion, and assumed, since the test of higher predictive value would be the reexposure to the drug, which is contraindicated in most cases. ${ }^{3}$

Hepatotoxicity is a known adverse effect, however unusual, of flucloxacillin. Its prevalence in the first exposure has been estimated at 1/10,000, and most cases occur after three months. Hepatotoxicity induced by flucloxacillin is a B-type or idiosyncratic reaction. ${ }^{4}$ This type of reaction occurs in an unpredictable way, often regardless of the dose, and usually at therapeutic levels. It presents a low incidence, a phase of variable latency, and there are usually immune mechanisms involved. The anatomopathological lesions are uncharacteristic and uneven. Systemic manifestations, such as fever, rash, arthralgia, eosinophilia, leukocytosis, and appearance of autoantibodies are frequent..$^{2.3}$ Due to its rarity and unpredictability, these are rarely detected in pre-clinical or clinical trials of drugs. In addition, its reduced incidence makes it even more difficult to investigate it in epidemiological studies. ${ }^{4}$

The most common risk factors for flucloxacillin-related hepatotoxicity are the female gender, age above 60 years, and duration of treatment exceeding two weeks. ${ }^{4}$ The HLA system plays a key role in immune-mediated adverse reactions to drugs. The HLA-B ${ }^{*} 5701$ allele is common in northern Europe, and it is estimated that it occurs in $6-8 \%$ of the general European population. Studies show that $84.3 \%$ of patients with hepatitis due to flucloxacillin have the HLA-B ${ }^{*} 5701$ and 80 times greater risk of being affected. ${ }^{5}$ HLA typing can substantiate the diagnosis of hepatotoxicity due to specific drugs; however, its validation is required before recommending routine implementation, since it is currently not cost-effective. ${ }^{2}$

The diagnosis of hepatotoxicity depends on a high index of suspicion and is based on a compatible temporal relationship, a suggestive analytical pattern of liver enzymology, improvement after suspension of the drug (with known toxicity), concomitant manifestations of hypersensitivity, exclusion of other etiologies, and application of diagnosis scales. ${ }^{6}$ Lymphocyte transformation tests may also be useful. ${ }^{3} \mathrm{~A}$ liver biopsy can substantiate the clinical suspicion of hepatotoxicity, provide important information about its severity, and help exclude other potential causes of liver injury; ${ }^{7}$ however, there are no histological characteristics that unequivocally confirm the diagnosis. ${ }^{\mathbf{7 . 8}}$

\section{CLINICAL CASE}

A man, 74 years old, self-employed, metallurgical worker, attended the emergency service due to asthenia, anorexia, nausea, abdominal discomfort, and mild fever (maximum axillary temperature of $38.1^{\circ} \mathrm{C}$ ) with three days of evolution. There was a reference to two previous eight-day cycles of antibiotic therapy with flucloxacillin $500 \mathrm{mg}$ 8/8h due to erysipelas (three months and two weeks prior to admission). He had a history of monoclonal gammopathy under investigation, previous brucellosis for nearly 30 years, benign prostate hypertrophy treated with transurethral resection, and left inguinal hernioplasty. There was no usual chronic medication. Alcohol habit: $24 \mathrm{~g} /$ day. There were no other noteworthy habits.

Upon objective examination, the patient was hemodynamically stable, feverless, with hydrated and rosy mucous membranes, subicteric. His abdomen was soft, without palpable masses or enlarged organs, with slight discomfort upon general palpation, without defense or signs of peritoneal irritation, with air-fluid noises of normal timbre. There was no evidence of chronic liver disease.

Analysis showed hemoglobin 15.0 g/dL, VGM 92.6 fL, leucocytes $5.6 \times 10^{9} / \mathrm{L}$, platelets $185 \times 10^{9} / \mathrm{L}$, AST 349 U/L (N: 4-43), ALT 646 U/L (N: 4-43), FA 302 (N: 25-100) U/L, GGT 652 U/L (N: 7.0-49.0), total bilirubin $3.3 \mathrm{mg} / \mathrm{dL}(\mathrm{N}: 0.3-1.2)$, direct bilirubin $2.72 \mathrm{mg} / \mathrm{dL}(\mathrm{N}$ : 0.10-0.50), normal LDH, amylase, and lipase, normal coagulation, and albumin $4.0 \mathrm{~g} / \mathrm{dL}$. Renal function and ionogram without alterations, CRP $3.96 \mathrm{mg} / \mathrm{dL}$ $(\mathrm{N}<0.50)$ (Table 1). An abdominal ultrasound showed liver, pancreas, and spleen without evidence of lesions of acute nature; the gallbladder was a bit distended, without other evident changes.

The patient was admitted for investigation and monitoring. An additional etiologic study found ferritin $642.0 \mathrm{ng} / \mathrm{mL}(\mathrm{N}: 22.0$ - 322.0) with normal remaining iron kinetics. Serum protein electrophoresis had a 
Gama monoclonal peak, and immunoelectrophoresis of serum proteins showed the presence of antiserum lambda monoclonal IgG bands. Ceruloplasmin; normal serum and urinary copper and alpha-1 antitrypsin.
Autoimmunity assay and hepatotropic viruses were negative.

A cholangial MRI was performed and showed the liver with normal dimensions and regular contours,

TABLE 1. ANALYTICAL INVESTIGATION OF THE PATIENT.

\begin{tabular}{|c|c|c|}
\hline Analysis & Results & Reference values \\
\hline \multicolumn{3}{|l|}{ Complete blood count } \\
\hline $\begin{array}{l}\text { Leukocytes } \\
\text { Neutrophils } \\
\text { Lymphocytes } \\
\text { Monocytes } \\
\text { Eosinophils } \\
\text { Basophils } \\
\end{array}$ & $\begin{array}{l}5.6 \times 10^{9} / \mathrm{L} \\
2.4 \times 10^{9} / \mathrm{L}(42.8 \%) \\
1.5 \times 10^{9} / \mathrm{L}(27.0 \%) \\
0.9 \times 10^{9} / \mathrm{L}(16.7 \%) \\
0.7 \times 10^{9} / \mathrm{L}(13.0 \%) \\
0.0 \times 10^{9} / \mathrm{L}(0.5 \%)\end{array}$ & $4.5-11.5$ \\
\hline Hemoglobin & $15.0 \mathrm{~g} / \mathrm{dL}$ & $14.0-18.0$ \\
\hline Platelets & $185 \times 10^{9} / \mathrm{L}$ & $150.0-450.0$ \\
\hline \multicolumn{3}{|l|}{ Coagulation and Hemostasis } \\
\hline Prothrombin index & $89 \%$ & $70.0-100.0$ \\
\hline INR & 1.06 & \\
\hline APTT & 28.8 seconds & $21.9-32.9$ \\
\hline \multicolumn{3}{|l|}{ Biochemistry } \\
\hline Albumin & $4.0 \mathrm{~g} / \mathrm{dL}$ & $3.5-5.0$ \\
\hline Amylase & $20 \mathrm{UI} / \mathrm{L}$ & $8-53$ \\
\hline Lipase & $22 \mathrm{UI} / \mathrm{L}$ & $6-51$ \\
\hline $\mathrm{LDH}$ & $551 \mathrm{UI} / \mathrm{L}$ & $200-480$ \\
\hline CK & $101 \mathrm{UI} / \mathrm{L}$ & $0-165$ \\
\hline CRP & $3.96 \mathrm{mg} / \mathrm{dL}$ & $<0.50$ \\
\hline Procalcitonin & $0.29 \mathrm{ng} / \mathrm{mL}$ & $0.01-0.64$ \\
\hline Iron & $140.1 \mu \mathrm{g} / \mathrm{dL}$ & $45.0-182.0$ \\
\hline Ferritin & $642.0 \mathrm{ng} / \mathrm{mL}$ & $22.0-322.0$ \\
\hline Total capacity of iron binding & $286.2 \mu \mathrm{g} / \mathrm{dL}$ & 258.9-388.0 \\
\hline Transferrin & $219.5 \mathrm{mg} / \mathrm{dL}$ & $180.0-380.0$ \\
\hline Ceruloplasmin & $40.30 \mathrm{mg} / \mathrm{dL}$ & $22.0-58.0$ \\
\hline Alpha-1 antitrypsin & $172.0 \mathrm{mg} / \mathrm{dL}$ & $80.0-199.0$ \\
\hline Urinary copper & $38 \mu \mathrm{g} / \mathrm{L}$ & $9-62$ \\
\hline \multicolumn{3}{|l|}{ Infectious Serologies } \\
\hline $\begin{array}{l}\text { CMV, EBV, Hepatitis B and C, Syphilis, HIV, Brucellosis, } \\
\text { Leptospira, Borrelia, Coxiella }\end{array}$ & \multicolumn{2}{|c|}{ Negative for acute infection } \\
\hline \multicolumn{3}{|l|}{ Immunoelectrophoresis } \\
\hline Serum IgG & $2228.0 \mathrm{mg} / \mathrm{dL}$ & $650.0-1600.0$ \\
\hline Serum $\lg A$ & $138.0 \mathrm{mg} / \mathrm{dL}$ & $40.0-350.0$ \\
\hline Serum IgM & $39.0 \mathrm{mg} / \mathrm{dL}$ & $50.0-300.0$ \\
\hline Serum Kappa light chains & $389.0 \mathrm{mg} / \mathrm{dL}$ & 598.0-1329.0 \\
\hline Serum lambda light chains & $1170.0 \mathrm{mg} / \mathrm{dL}$ & $280.0-665.0$ \\
\hline Serum IgG antiserum and lambda & \multicolumn{2}{|c|}{ Presence of monoclonal bands } \\
\hline Urinary immunoelectrophoresis & \multicolumn{2}{|l|}{ No changes } \\
\hline \multicolumn{3}{|l|}{ Endocrinology } \\
\hline $\mathrm{TSH}$ & $0.157 \mathrm{mUI} / \mathrm{L}$ & $0.350-5.500$ \\
\hline $\mathrm{T} 3 \mathrm{~L}$ & $2.9 \mathrm{pg} / \mathrm{mL}$ & $2.0-4.2$ \\
\hline $\mathrm{T} 4 \mathrm{~L}$ & $1.2 \mathrm{pg} / \mathrm{mL}$ & $0.9-1.8$ \\
\hline Ac- Anti-TSH receptor & Negative & \\
\hline \multicolumn{3}{|l|}{ Immunology } \\
\hline $\begin{array}{l}\text { ANA, Ac anti-DNA, ENA screen, antimitochodria, anti-M2, } \\
\text { anti-SP100, anti-smooth muscle, anti-factin, anti-SLA/LP, } \\
\text { anti-LKM1, anti-LC1, anti-MPO, and anti-PR3 }\end{array}$ & Negative & \\
\hline
\end{tabular}


smooth texture, without focal lesions. There were no pathologies of the biliary tract. Bone marrow biopsy and examination were consistent with monoclonal gammopathy of undetermined significance.

During hospitalization, the patient remained feverless, hemodynamically stable, without abdominal pain, and analytically without elevation of parameters that were inflammatory or suggestive of an infectious process. We observed decreasing profile values of AST, ALT, GGT, and AP (although the latter with variations) (Fig. 1); however, there was progressive worsening of the values of bilirubin, reaching $24.1 \mathrm{mg} / \mathrm{dL}$ for total bilirubin and $22.32 \mathrm{mg} / \mathrm{dL}$ for direct, with development of jaundice, pruritus, and choluria, without coagulopathy or encephalopathy.

Based on the application of diagnosis scales, the sum of the scores from the Maria and Vitorino ${ }^{\text {i9 }}$ scale is 13 points (possible causality), and from the Rucam ${ }^{10}$ scale is 8 points (likely causality). Once hepatotoxicity was confirmed, in this follow-up, treatment with ursodeoxycholic acid was started at $1,500 \mathrm{mg} /$ day, in the 21st day of hospitalization.

The liver biopsy later revealed slight multifocal steatosis (predominantly microvesicular); accentuated changes in the centrilobular areas (sinusoidal dilatation, marked congestion, hemorrhage, and multifocal collapse of hepatocytes); expansion of the portal areas with development of bridges; proliferated bile ducts and inflammatory infiltrate of variable density, predominantly of the mononuclear type. The test for amyloid substance using Congo red staining was negative. HLA-B*5701 typing was performed with positive results.

After flucloxacillin had been suspended for four months, there was clinical and analytical improvement with AST 60 U/L, ALT 83 U/L, FA 222 U/L, GGT 190.3 $\mathrm{U} / \mathrm{L}$, total bilirubin $1.4 \mathrm{mg} / \mathrm{dL}$ and direct bilirubin 1.06 $\mathrm{mg} / \mathrm{dL}$. About a year later, there was still a slight elevation of FA (114 U/L) and GGT 99.5 U/L with the other liver enzymology figures within the normal range; after 18 months, only GGT remained high.

\section{DISCUSSION}

The clinical case in question presents a case of mixed hepatotoxicity - R-value of 4.97 [R=(ALT/upper limit of normality)/(FA/upper limit of normality)]. ${ }^{2.6}$ It is recognized that the period between the first dose of flucloxacillin and the beginning of laboratory manifestations was approximately three months and two weeks after re-exposure to the drug, possibly having started earlier, although it is not possible to affirm it objectively. The age of the patient, the concomitance of monoclonal gammopathy under investigation, and exuberance of analytical raised the hypothesis of infiltrative liver disease, in particular, due to amyloidosis, which, similarly to other possible etiologies, was excluded. Then, mild fever and eosinophilia were considered extra-hepatic manifestations of hepatotoxicity.

With respect to the analytical developments (Fig. 1 ), we could initially verify an analytical pattern of hepatotoxicity even more suggestive of hepatocellular

FIGURE 1.

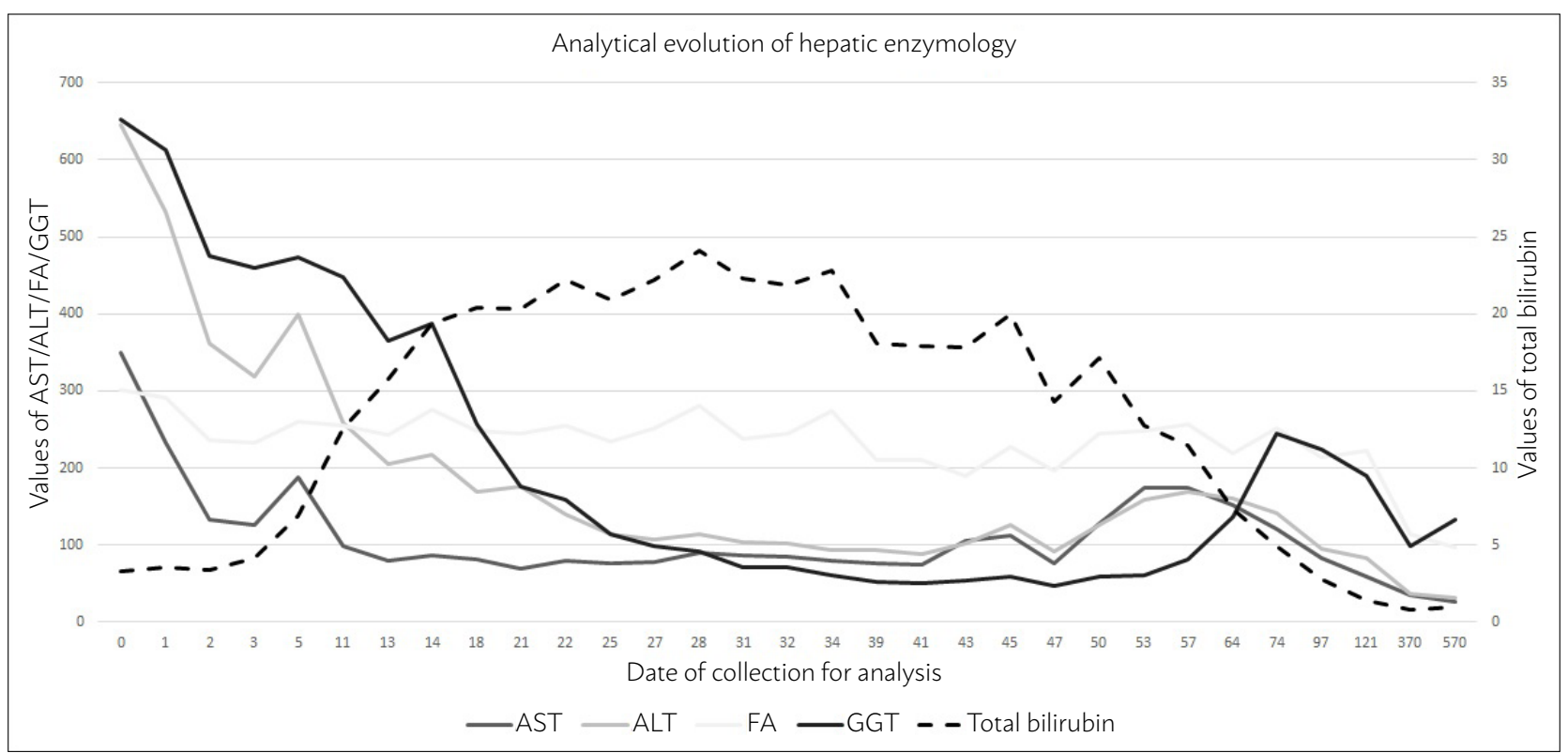


and, at a later stage later, compatible with a cholestatic pattern. It should be noted that the biochemical categorization of the hepatotoxicity pattern is not always indicative of the underlying pathological pattern. ${ }^{7.8}$

According to the classifications of hepatotoxicity severity, this case can be classified as moderate (International Dili Expert Working Group) or moderate-severe (US Drug-Induced Liver Injury Network). ${ }^{2}$

The anatomopathological findings showed signs that may be associated with a worse prognosis, with the need for liver transplantation and higher mortality, namely the presence of microvesicular steatosis, hepatocyte necrosis, cholangial cholestasis, and duct proliferation. $^{2}$

In the absence of an antidote, the basis for the treatment of toxic hepatitis is based on the suspension of the drug and therapeutic support. In patients with evidence of hepatic cholestasis, ursodeoxycholic acid may be a therapeutic alternative, although its effectiveness is limited, and its use is controversial. ${ }^{2.11}$ In the presence of hepatotoxicity associated with systemic hypersensitivity and characteristics compatible with autoimmune hepatitis, corticosteroid therapy can be considered, although the evidence is also limited. ${ }^{2.11}$

The presence of jaundice concomitant to the hepatotoxicity scenario is associated with approximately $10 \%$ likelihood of risk of progression to fatal liver failure. Generally, the hepatocellular pattern is associated with a worse prognosis and high mortality. The cholestatic pattern can also be associated with significant mortality, while the mixed pattern seems to be associated with a lower risk. ${ }^{2}$

\section{CONCLUSION}

The authors present a case of mixed hepatotoxicity due to flucloxacillin that caused prolonged hospitalization and comprehensive etiological study. Despite the moderate to severe analytical presentation and the histological findings indicative of poor prognosis, there was favorable evolution, without clinical evidence of coagulopathy or encephalopathy. The analytical normalization was, however, slow, with progression to chronicity. Studies associating the HLA-B*5701 allele with susceptibility to toxicity by flucloxacillin have been reported in the literature. Although this is still not a cost-effective screening, it allows identifying susceptible individuals, preventing exposure to the drug, or indicating the need for closer monitoring. Lastly, it allows substantiating the diagnosis.

\section{Contribution of the authors}

Monica Teixeira was responsible for interpreting the case, designing, and writing the article. Sara Macedo contributed to designing and writing the article. Tânia Batista contributed to designing and writing the article. Sofia Martins contributed to interpreting the case and writing the article. Andreia Correia contributed by critically reviewing the article. Luis Costa Matos contributed by critically reviewing the article.

\section{Conflicts of Interest}

The authors declare there are no conflicts of interest associated with this publication.

\section{RESUMO}

A hepatotoxicidade à flucloxacilina é rara e classifica-se como idiossincrática, uma vez que é dependente da suscetibilidade individual, não expectável e independente da dose.

Apresentamos o caso de um homem, 74 anos, antecedentes de gamapatia monoclonal e hábitos alcoólicos de $24 \mathrm{~g} / \mathrm{dia}$, com quadro de astenia, anorexia, náuseas, desconforto abdominal e febrícula com três dias de evolução. Referência a dois ciclos de antibioterapia com flucloxacilina por erisipela (três meses e duas semanas antes da admissão). Analiticamente com AST 349 U/L, ALT 646 U/L, FA $302 \mathrm{U} / \mathrm{L}$, GGT $652 \mathrm{U} / \mathrm{L}$, bilirrubina total 3,3 mg/dL, bilirrubina direta 2,72 mg/dL. Excluídas etiologias infecciosa, autoimune, metabólica, bem como patologia das vias biliares por colangio-RM. Biópsia hepática mostrou esteatose multifocal ligeira (predominantemente microvesicular); alterações acentuadas nas áreas centrolobulares (dilatação sinusoidal, congestão acentuada, hemorragia e colapso multifocal de hepatócitos); expansão das áreas portais com constituição de pontes; ductos biliares proliferados e infiltrado inflamatório de densidade variável, predominantemente de tipo mononucleado. Tipagem de HLA-B*5701 positiva. Agravamento analítico atingindo bilirrubina total $24,1 \mathrm{mg} / \mathrm{dL}$, com desenvolvimento de icterícia, prurido e colúria. Admitida a hepatotoxicidade, iniciou terapêutica com ácido ursodesoxicólico. Verificou-se evolução favorável, sem evidência de coagulopatia ou encefalopatia. A normalização analítica foi, no entanto, lenta, com evolução para cronicidade.

Os autores apresentam este caso para alertar para a possibilidade de hepatotoxicidade moderada a grave à flucloxacilina, antibiótico de uso comum na prática clínica e associação com o alelo HLA-B*5701 relatada na literatura. 


\section{REFERENCES}

1. Chalasani N, Björnsson E. Risk factors for idiosyncratic drug-induced liver injury. Gastroenterology. 2010;138(7):2246-59.

2. European Association for the Study of the Liver. EASL clinical practice guidelines: drug-induced liver injury. J Hepatol. 2019;70(6):1222-61.

3. Matos LC, Martins B. Hepatites tóxicas: revisão da literatura. Rev Soc Port Med Inter. 2005;12(4):239-58.

4. Russmann S, Kaye JA, jick SS, Jick H. Risk of cholestatic liver disease associated with flucloxacillin and flucloxacillin prescribing habits in the UK: cohort study using data from the UK General Practice Research Database. Br | Clin Pharmacol. 2005;60(1):76-82.

5. Daly AK, Donaldson PT, Bhatnagar $P$, Shen $Y$, Pe'er I, Floratos $A$, et al; DILIGEN Study; International SAE Consortium. HLA-B*5701 genotype is a major determinant of drug-induced liver injury due to flucloxacillin. Nat Genet. 2009;41(7):816-9.

6. Chalasani NP, Hayashi PH, Bonkovsky HL, Navarro VI, Lee WM Fontana RJ; Practice Parameters Committee of the American College of Gastroenterology. ACG Clinical Guideline: the diagnosis and management of idiosyncratic drug-Induced liver injury. Am | Gastroenterol. 2014;109(7):950-66.
7. Kleiner DE, Chalasani NP, Lee WM, Fontana RJ, Bonkovsky HL, Watkins PB, et al; Drug-Induced Liver Injury Network (DILIN). Hepatic histological findings in suspected drug-induced liver injury: systematic evaluation and clinical associations. Hepatology. 2014;59(2):661-70

8. Goodman ZD. Phenotypes and pathology of drug-induced liver disease. Clin Liver Dis. 2017;21(1):89-101.

9. National Institutes of Health, U.S. Department of Health \& Human Services. Maria and Victorino (M\&V) system of causality assessment in drug induced liver injury. [cited 2018 Apr 20]. Available from: https://livertox. nih.gov/MVcausality.html

10. National Institutes of Health, U.S. Department of Health \& Human Services. Roussel Uclaf Causality Assessment Method (RUCAM) in drug induced liver injury. [cited 2018 Apr 20]. Available from: https://livertox.nih.gov/ rucam.html

11. Gonzalez HC, lafri SM, Gordon SC. Management of acute hepatotoxicity including medical agents and liver support systems. Clin Liver Dis. 2017;21(1):163-80 